\title{
Alpha-picolinic acid, a fungal toxin and mammal apoptosis-inducing agent, elicits hypersensitive-like response and enhances disease resistance in rice
}

\author{
Hai Kuo ZHANG ${ }^{1}$, Xin ZHANG ${ }^{1}$, Bi Zeng MAO ${ }^{2,}$ Qun LI ${ }^{1}$, Zu Hua HE ${ }^{1,2^{*}}$ \\ ${ }^{1}$ SHARF and National Laboratory of Plant Molecular Genetics, Shanghai Institute of Plant Physiology and Ecology, \\ Shanghai Institutes for Biological Sciences, Chinese Academy of Sciences, Shanghai 200032, China. \\ ${ }^{2}$ Biotechnology Institute, Zhejiang University, Hangzhou 310029, China.
}

\begin{abstract}
Alpha-picolinic acid (PA), a metabolite of tryptophan and an inducer of apoptosis in the animal cell, has been reported to be a toxin produced by some of plant fungal pathogens and used in screening for disease resistant mutants. Here, we report that PA is an efficient apoptosis agent triggering cell death of hypersensitive-like response in planta. Confirmed by Fluorescence Activated Cell Sorter (FACS), rice suspension cells and leaves exhibited programmed cell death induced by PA. The PA-induced cell death was associated with the accumulation of reactive oxygen species that could be blocked by diphenylene iodonium chloride, indicating that the generation of reactive oxygen species was NADPHoxidase dependent. We also demonstrated the induction of rice defense-related genes and subsequent resistant enhancement by PA against the rice blast fungus Magnaporthe grisea. Hence, it was concluded that the PA-stimulated defense response likely involves the onset of the hypersensitive response in rice, which also provides a simple eliciting tool for studying apoptosis in the plant cell.
\end{abstract}

Keywords: picolinic acid, cell death, hypersensitive responses, Magraporche grisea, rice.

\section{INTRODUCTION}

Alpha-picolinic acid (PA), a nicotinic acid analog, is one component of the naturally occurring degradation of tryptophan. In animal cells, PA is synthesized in the liver, kidney, and other organs[1]. During the past decades, PA was found to have a number of biological functions. Early researches showed that PA was a specific chelator and had effects on incorporation of metal ions such as $\mathrm{Zn}^{2+}$, $\mathrm{Fe}^{2+}$, and $\mathrm{Cu}^{2+}[2]$. The treatment with PA disordered the cell growth and arrested cell cycle[3, 4]. Inhibition of mycobacterial growth by PA was found to depend on cell apoptosis, and this effect was enhanced by IFN- $\gamma$ treatment $[5,6]$. PA also has protective and therapeutic effects against tumor through activation and subsequent enhancement of macrophages-mediated cytotoxicitiy, and induces production of tumor-related proteins[7-9]. Intriguingly, PA stimulates programmed cell death (PCD) in cancer cells and efficiently interrupts the progress of HIV in vitro[ $[10$, $11]$.

PCD, known as apoptosis, is a genetically determined process in all multicellular organisms characterized by a battery of morphological and biochemical changes such

"Corresponding author: $\mathrm{Zu}$ Hua HE,

Tel: +86 2164042090 ext 6572, Fax: +86 2164042385 ,

E-mail: zhe@iris.sipp.ac.cn as nuclear condensation, cytoplasm shrinkage and subsequent cell death. PCD is the most striking event of the plant hypersensitive response (HR) in the incompatible interaction between plants and microbes, and is regarded as a defensive suicide of plant cells against an avirulent pathogen. The HR at the infected sites is the primary and local response in the gene-for-gene resistance[12], similar to apoptosis in animal cells in many aspects including caspase activity[13, 14]. The HR is usually associated with an oxidative burst $[15,16]$. Rapid generation of reactive oxygen species (ROS) including hydrogen peroxide $\left(\mathrm{H}_{2} \mathrm{O}_{2}\right)$ and superoxide $\left(\mathrm{O}^{2-}\right)$ acts as a central component and primary process of plant defense responses to pathogen challenge[17]. Besides PCD, other early resistance responses include cell wall reinforcement, production of antimicrobial components, and activation of pathogenesis-related (PR) genes. Following the HR, systemic acquired resistance (SAR) develops to prevent following infection of virulent pathogens in distal tissues[18].

A wide variety of elicitors, most are of pathogen origin, capable to stimulate host defense responses, facilitate studies on the complicated signaling during the plant HR. For instance, syringolin A isolated from the nonhost pathogen Pseudomonas syringae pv syringae initiated wheat hypersensitive cell death and enhanced resistance to powdery 
mildew, and was also recognized by rice cell[19]. The fungal cerebrosides including cerebrosides $\mathrm{B} 1$ and $\mathrm{C}$ were shown to elicit the hypersensitive cell death and phytoalexin accumulation in rice plants[20]. Similarly, nonprotein amino acid, b-aminobutyric acid (BABA) which has biological effects known in animal cells, was also reported to protect Arabidopsis against the oomycete pathogen Peronospora parasitica through activation of natural defense mechanisms such as callose deposition and the formation of trailing necroses[21]. Some of plant fungal pathogens such as Magnorpathe grisea (M. grisea) and Fusarium spp. also produce PA as one of main toxins that might contribute to their pathogenesis[22, 23]. Interestingly, based on the fact that PA induces disease-like lesions on leaves, PA has been used to screen rice mutants for disease resistance to $M$. grisea in several laboratories $[24,25]$. However, the mechanism of the PA-induced lesion-mimics and its impact on disease resistance remain largely unknown. We conducted studies of the mechanism of the PA-stimulated cell death and defense responses in rice, and found that PA could induce HR-like responses including PCD, an oxidative burst and defense gene activation in rice, and disease resistance could be enhanced against $M$. grisea by exogenous PA application.

\section{MATERIALS AND METHODS}

\section{Materials}

The rice (Oryza sativa L.) near isogenic-lines H7R (resistant) and H7S (susceptible) were used[26]. PA ( $\alpha$-picolinic acid or 2-picolinic acid) (Sigma) was freshly prepared for use. M. grisea 01-19 B15 was provided by Prof. G. Sun (Zhejiang Academy of Agricultural Sciences). The rice suspension cells were made from the japonica variety Taipei 309. All experiments were repeated at least 3 times.

\section{Cell death detection}

Rice suspension cells were incubated with PA at different concentrations for $24 \mathrm{~h}$. Cell death was quantified by Evans blue binding as previously described [27]. Cells were heated for $10 \mathrm{~min}$ at $80{ }^{\circ} \mathrm{C}$ for mimicking complete $(100 \%)$ cell death control. Percentages of cell death in treatments were calculated by comparing dye-binding levels with that of heat-killed cells. To detect PCD on rice leaves, trypan blue staining was performed as described[28]. Detached leaves were stained by boiling for $8 \mathrm{~min}$ in alcoholic lactophenol ( $96 \%$ ethanollactophenol 1:1 [V/V] containing $0.1 \mathrm{mg} \mathrm{ml}^{-1}$ trypan blue) and cleared in $70 \%$ chloral hydrate solution overnight, then reserved in $70 \%$ glycerol. For directly detecting cell apoptosis by Fluorescence Activated Cell Sorter (FACS), protoplasts were prepared from the suspension cells[29], and flow cytometry was performed on a FACS (Becton-Dickinson) based on O'Brien et al[30].

\section{$\mathrm{H}_{2} \mathrm{O}_{2}$ detection}

The production of $\mathrm{H}_{2} \mathrm{O}_{2}$ was monitored in culture cell by measuring the oxidative quenching of pyranine $\left(\lambda_{\mathrm{ex}}=405 \mathrm{~nm}, \lambda_{\mathrm{em}}=512 \mathrm{~nm}\right)$ in Fluorometry PE LS50B (Perkin Elmer) as previously described
[31]. Diphenylene iodinium (DPI, Sigma) $(10 \mu M)$ and catalase (120 units $\mathrm{ml}^{-1}$ ) (Sigma) were added to the cell culture $30 \mathrm{~min}$ prior to PA treatment to test possible $\mathrm{H}_{2} \mathrm{O}_{2}$ origin of NADPH oxidase-dependence and effect of $\mathrm{H}_{2} \mathrm{O}_{2}$ abolish on cell death. For detecting $\mathrm{H}_{2} \mathrm{O}_{2}$ accumulation in rice leaves, 3, 3-diaminobenzidine (DAB) uptake was adopted[32]. Briefly, leaves were cut from two-week-old rice seedlings pretreated with different concentrations of PA for $24 \mathrm{~h}$ and placed in $1 \mathrm{mg} \mathrm{ml}^{-1} \mathrm{DAB}-\mathrm{HCl}, \mathrm{pH} 3.8$ (Sigma). DAB uptake was detected in leaves cleared in boiling ethanol $(96 \%)$ for $10 \mathrm{~min}$. Stable reddish-brown DAB polymerizing sediments were visible in the leaf tissue undergoing HR.

\section{Northern blot analysis}

Total RNA was isolated from the control and PA-treated seedlings using TRIzol reagent (GIBCO BRL). Each $30 \mu \mathrm{g}$ of total RNA was separated on formaldehyde-agarose gels, blotted to nylon membrane, and hybridized with the ${ }^{32} \mathrm{P}$-labeled rice defense gene probes, PAL, RCH10[27], PIR-2[33], and gp91phox homolog OsRboha[34]. Hybridization and detection were performed as previously described[27].

\section{Pathogen inoculation and disease resistance}

Rice seedlings of $\mathrm{H} 7 \mathrm{R}$ and $\mathrm{H} 7 \mathrm{~S}$ lines were grown at $26-28{ }^{\circ} \mathrm{C}$ for 2 weeks. Seedlings were pretreated with $0.5 \mathrm{mg} \mathrm{ml}^{-1} \mathrm{PA}$ for $12 \mathrm{~h}$, then spray-inoculated with $3 \times 10^{5}$ spores $\mathrm{ml}^{-1}$ of $M$. grisea $\mathrm{B} 15$ in $0.02 \%$ tween-20 solution in the dark dew chamber with saturated humidity at $26-28{ }^{\circ} \mathrm{C}$ for $24 \mathrm{~h}$, followed by growth under $14 / 10 \mathrm{~h}$ (light/dark), $26-28^{\circ} \mathrm{C}$ and $90 \%$ relative humidity. Disease development was recorded in the leaves 3-7 days postinoculation with the resistant H7R plants and $0.02 \%$ tween-20 pretreatment as the controls. Disease degree was ranked as 0 to 5[35]. To test whether spore germination was directly inhibited on the PA-pretreated leaf surface, spore germinating ratio was calculated in leaf surfaces after $24 \mathrm{~h}$ postinoculation, with $0.02 \%$ tween- 20 pretreatment as the control.

\section{RESULTS}

\section{PA induced cell death in rice leaves and suspension cells}

We found that PA $\left(1 \mathrm{mg} \mathrm{ml}^{-1}\right)$ could induce obvious cell death lesions (lesion-mimics) on rice leaves $24 \mathrm{~h}$ after treatment (Fig 1A). In order to support the hypothesis that PA elicited the establishment of plant HR and the formation of death lesions was a result of apoptosis process start-up, trypan blue stain was performed as usual[28] (Fig 1B). The result showed that PA induced significant HR-like cell death on leaves, and induction of cell death was PA dosedependent since cell death increased with higher PA doses.

To dissect cell death induced by PA in detail, rice cell suspension was incubated with different PA concentrations of $0,03,0.5,1.0$ and $3.0 \mathrm{mg} \mathrm{ml}^{-1}$. As expected, treatment with PA $1.0 \mathrm{mg} \mathrm{ml}^{-1}$ and higher concentration induced near complete cell death $24 \mathrm{~h}$ post-incubation (Fig $2 \mathrm{~A}$ ). During the incubation with $1 \mathrm{mg} \mathrm{ml}^{-1}$ of PA, cell death was detectable at as early as $4 \mathrm{~h}$, and the peak level of cell death arrived at $24 \mathrm{~h}$ (Fig 2B). And we found that $0.5 \mathrm{mg}$ 


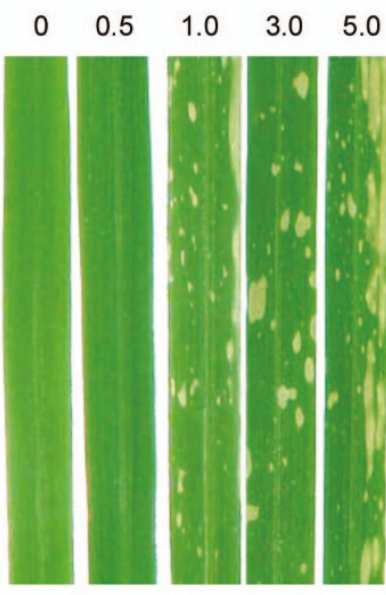

A

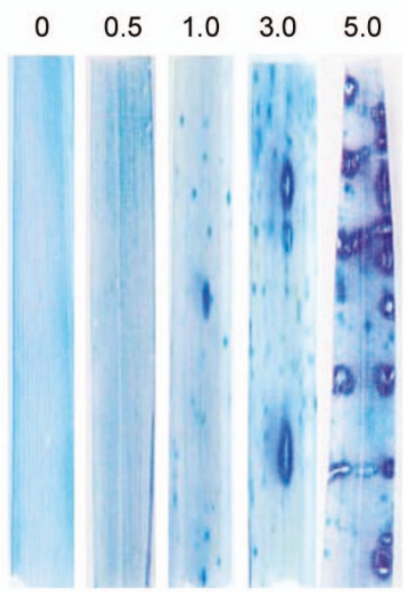

B
Fig 1. Cell death induced by PA on rice leaves. Two to three-weekold rice seedlings were sprayed with different concentrations of PA $\left(0.1,0.5,1.0,3.0\right.$ to $\left.5.0 \mathrm{mg} \mathrm{ml}^{-1}\right)$. (A) Cell death lesions were visible when the dose reached $1.0 \mathrm{mg} \mathrm{ml}^{-1}$ and death spots increased in size with higher PA concentrations. (B) Trypan blue staining showed cell death in the rice leaves treated for $24 \mathrm{~h}$ with the same PA concentrations as (A). $\mathrm{ml}^{-1} \mathrm{PA}$ could induce about $50 \%$ cell death of the suspension cells, while this concentration neither affected cell viability nor caused cell death lesions in leaves significantly, thereby we used this concentration in following studies of gene activation and disease resistance.

For the direct evidence of PCD induced by PA, we conducted flow cytometry analysis with rice protoplasts. Our test showed that PA indeed induced significant apoptosis in the rice suspension cells (Fig 2C). Because rice suspension cells never develop as individual cells, only small cell bodies (small calli), cells would be damaged during the preparation of protoplasts, therefore, exhibited some degree of apoptosis in the control. The FACS apoptosis value was less than the cell death ratio by Evans blue staining (Fig 2B, C), the explanation is that FACS can detects only cells of late apoptosis stage and Evans blue dyes all dead and dying cells.

\section{$\mathrm{H}_{2} \mathrm{O}_{2}$ accumulation in rice leaves and suspension cells treated by $\mathbf{P A}$}

It has been known that ROS get involved in the plant HR process and play an important role in the induction of
A

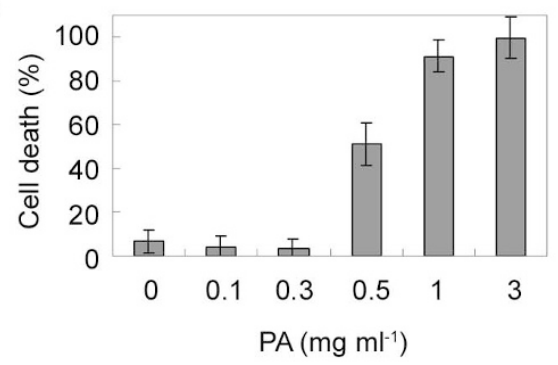

C

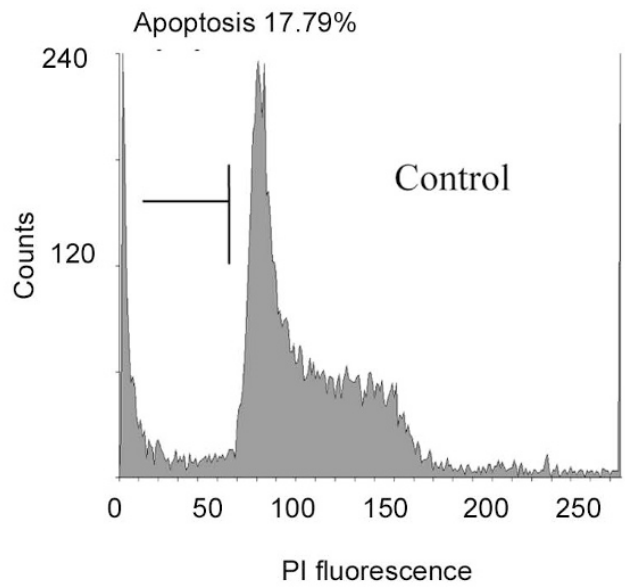

B

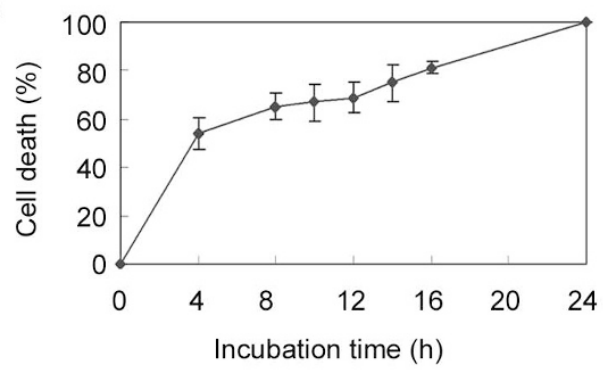

Apoptosis $47.21 \%$

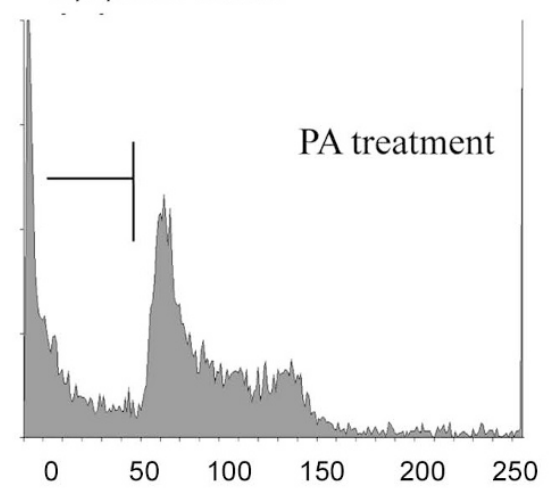

PI fluorescence

Fig 2. Cell death occurred in rice suspension cells incubated with PA. Using Evans dye binding, cell death was valued and the data is averages of at least 3 independent experiments with the standard deviations. (A) Cell death induced by different PA doses of 0.1 to $5.0 \mathrm{mg} \mathrm{ml}^{-1}$. (B) The time curve of cell death induced by PA $1.0 \mathrm{mg} \mathrm{ml}^{-1}$. (C) Apoptosis detection by FACS. Rice protoplast was incubated with PA $1.0 \mathrm{mg} \mathrm{ml}^{-1}$ for $24 \mathrm{~h}$ and then dyed with propidium iodide (PI). Fluorescence value represents DNA content per cell. The cells with DNA content less than haploid are ranged into apoptotic group indicated with bar and percent. 


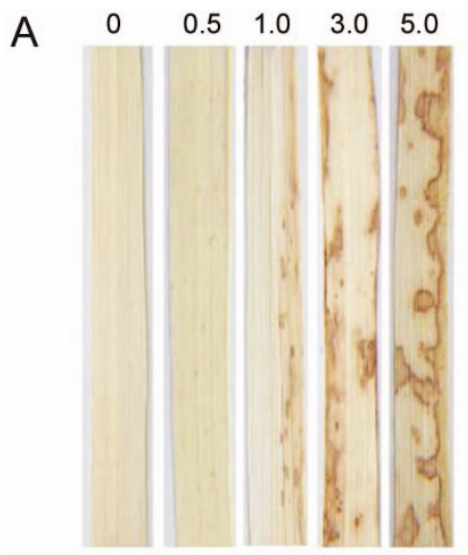

B

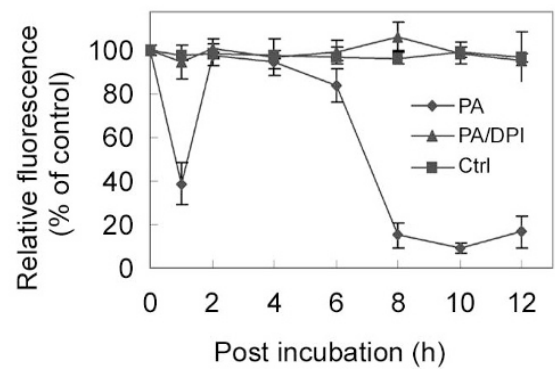

C

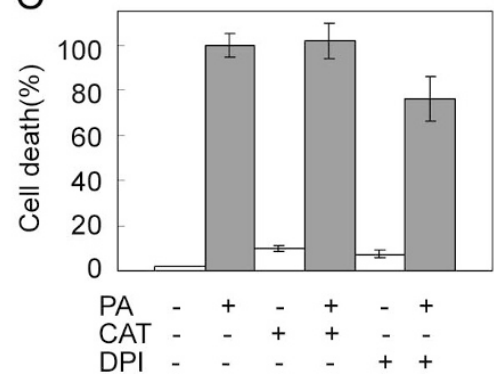

Fig 3. $\mathrm{H}_{2} \mathrm{O}_{2}$ generation induced by PA and blocked by DPI. (A) $\mathrm{H}_{2} \mathrm{O}_{2}$ accumulated on leaves treated with PA. The reddish-brown spots indicated the $\mathrm{H}_{2} \mathrm{O}_{2}$ sediments through DAB reaction. (B) A biphasic oxidative burst was monitored in the rice cell suspension incubated with PA $\left(0.5 \mathrm{mg} \mathrm{ml}^{-1}\right)$ by chemiluminescence approach. Note that lower relative fluorescence value indicated higher $\mathrm{H}_{2} \mathrm{O}_{2}$ contents and $\mathrm{H}_{2} \mathrm{O}_{2}$ generation was blocked by DPI $(10 \mu M)$. Ctrl, control. (C) PA-stimulated cell death was slightly repressed by DPI (10 $\mu M)$. Average values with standard deviations are shown.

SAR during the incompatible plant-microbe interaction. We conducted analysis of $\mathrm{H}_{2} \mathrm{O}_{2}$ generation in leaves and suspension cells treated with PA. The in situ accumulation of $\mathrm{H}_{2} \mathrm{O}_{2}$ was detected by DAB uptake (Fig $3 \mathrm{~A}$ ). DAB, when contacts with $\mathrm{H}_{2} \mathrm{O}_{2}$ in the presence of peroxidase, can polymerize instantly and locally to show a strong reddishbrown color. The result clearly showed that reddish-brown spots appeared around cell death region on the leaves treated, and increased in size and number as the PA dose increased. By a fluorescence approach, we also found that the suspension cells exhibited a biphasic burst of $\mathrm{H}_{2} \mathrm{O}_{2}$ production at $1 \mathrm{~h}$ and $8 \mathrm{~h}$ during incubation with $0.5 \mathrm{mg}$ $\mathrm{ml}^{-1} \mathrm{PA}$ (Fig 3B), similarly to the oxidative burst classically observed during an incompatible plant-microbe interaction[36].

It has been proposed that plants produce ROS via a NADPH oxidase system[34]. To confirm $\mathrm{H}_{2} \mathrm{O}_{2}$ generation of the NADPH oxidase origin in PA-treated cells, DPI, a NADPH oxidase inhibitor, was added to the PA-incubated cells. The result showed that DPI could totally inhibit the oxidative burst in the cells treated with PA (Fig 3B), indicating of NADPH oxidase-dependence. However, cell death induced by PA was not significantly reduced by either DPI or catalase, a $\mathrm{H}_{2} \mathrm{O}_{2}$ scavenger (Fig $3 \mathrm{C}$ ), suggesting that the $\mathrm{H}_{2} \mathrm{O}_{2}$ accumulation were not very related to the cell death event. Those observations demonstrated that the PAinduced oxidative burst required a NADPH oxidase-dependent pathway.

\section{Expression of rice defense-related genes in}

\section{PA-treated cells}

The HR evokes downstream of plant defense pathways, including induction of defense-related genes. We analyzed transcript accumulation of some rice defense-related genes known to be activated during rice defense responses[27, 33]. The result showed that PA could induce the rice defense-related genes (Fig 4A). The transcripts of PAL, PIR2 and $\mathrm{RCH} 10$ started to accumulate 4 or $12 \mathrm{~h}$ after treatment with PA and the maximum accumulation was observed 12 or $24 \mathrm{~h}$ post-treatment, respectively. It also indicated that these defense-related genes, although all induced, had different induction patterns. Interestingly, we found that the rice gp91phox homolog, OsRboha, was not transcriptionally induced by PA, instead, its transcription was repressed by high PA level $\left(>1 \mathrm{mg} \cdot \mathrm{ml}^{-1}\right)$ after $12 \mathrm{~h}$ of treatments (Fig 4B, C). The result suggested that appropriate PA level could stimulate NADPH-oxidase to generate $\mathrm{H}_{2} \mathrm{O}_{2}$ (Fig 3). Taken together (Fig 1-4), we conclude here that PA induces rice defense activation in a similar way to the HR during pathogen attack or elicitor stimulation.

\section{Resistance enhancement against $M$. grisea in PA-pretreated plants}

The fact that PA stimulated the HR-like cell death, oxidative burst and defense-related gene expression, encouraged us to test its effect on disease resistance to rice blast $M$. grisea. Susceptible plants were pre-sprayed with PA then inoculated with the fungus as described above. As expected, we found that PA exhibited protective effect 


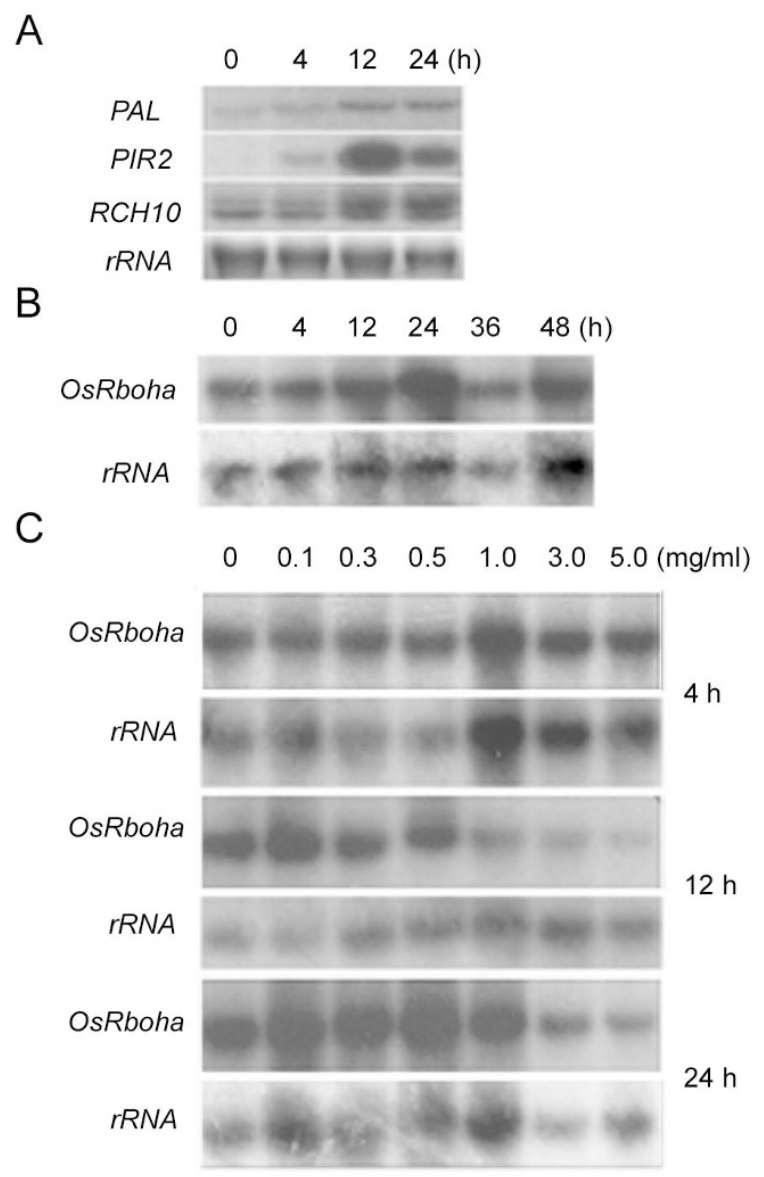

Fig 4. Expression of rice defense-related genes in PA-treated cells. (A) Northern blotting was performed to show induction of PAL, PIR2 and RCH10 genes in cells treated with $0.5 \mathrm{mg} \mathrm{ml}^{-1} \mathrm{PA}$ for 0 to 24 h. (B) Northern blotting indicated that OsRboha was not induced in cells treated with PA $\left(0.5 \mathrm{mg} \mathrm{ml}^{-1}\right)$. (C) Cells were treated with different PA doses for 4, 12 and $24 \mathrm{~h}$, and the transcription of OsRboha was monitored with Northern blotting, showing that higher PA doses of 1, 3 and $5 \mathrm{mg} \mathrm{ml}^{-1}$ repressed the transcription of OsRboha at 12 and $24 \mathrm{~h}$ after incubation.

against the fungus (Fig 5A). In the H7S leaves pretreated with PA $\left(0.5 \mathrm{mg} \mathrm{ml}^{-1}\right)$, disease symptom was greatly reduced and mostly fell into types 2 or 3 of lesions after 7 days of infection (Fig 5B), in contrast with lesion types 4 and 5 in the non-treated H7S control. Therefore, disease development was greatly slowed down by PA pretreatment. In order to answer the debate whether the PA-stimulated prevention of fungal infection resulted from its direct antifungal activity, we counted the germination ratio of the fungal spores on the PA-pretreated rice leaf surface, and no inhibitive effect on spore germination was observed for PA. Considering the inductive activity of PA on the HR-like defense, we concluded that PA conferred resistance against $M$. grisea through a defense activation mechanism in planta.
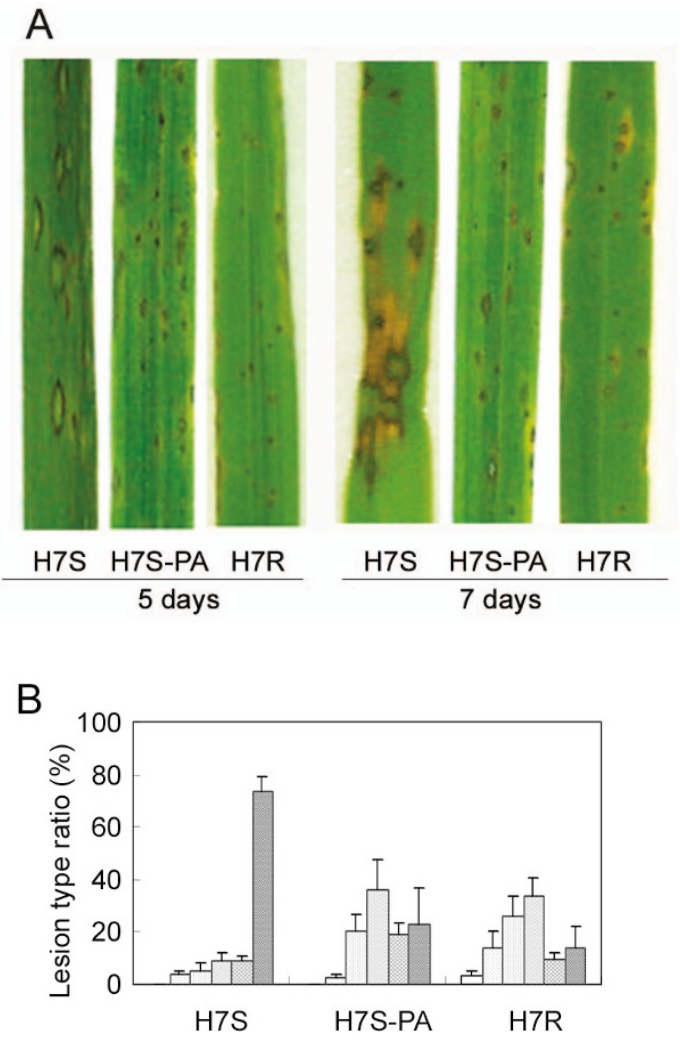

Fig 5. Enhanced protection against M. grisea by PA application. (A) Disease symptoms were photographed 5 and 7 days postinoculation. H7S-PA: PA $\left(0.5 \mathrm{mg} \mathrm{ml}^{-1}\right)$-pretreated susceptible plants, with non-treated H7S and H7R (resistant) as controls. (B) Lesion development on leaves of H7S treated and H7S and H7R control plants. Bars indicate ratios of lesion types 1, 2, 3, 4 and 5 , from left to right of each treatment. Average ratios with standard deviations are shown.

\section{DISCUSSION}

In this report, we demonstrated that PA, a mammal apoptosis-inducing agent, also had eliciting capacity to activate HR-like defense responses leading to cell death in either rice suspension cells or rice leaves (Fig 1, 2). Similar to the previous reports, we also detected PA from the M. grisea culture media by HPLC analysis (data not shown). In animal cells, PA has been shown to be a strong chelator of ions $\mathrm{Zn}^{2+}, \mathrm{Fe}^{2+}$ and $\mathrm{Cu}^{2+}$, and plays a role in macrophages-mediated tumor cell apoptosis[5-7, 10, 11]. The induction of apoptosis by PA might lies in its chelate activity leading to change of protein and gene activation $[8,9]$. One postulation is that PA exerts its effect probably through recognizing special zinc finger proteins[1]. Our observation that PA could induce HR-like cell death, an oxidative burst and defense-related gene activation suggests that the same mechanism might be underlying in the PA-mediated cell death process in plant. The change of 
the redox status involving NADPH oxidase at the cell membrane might account for the initiation of the HR-like program by PA.

The biphasic burst of $\mathrm{H}_{2} \mathrm{O}_{2}$ induced by PA exhibited similar fashion to the ROS release in an incompatible plantmicrobe interaction. Moreover, our current results also add support to the hypothesis that ROS is generated through a NADPH oxidase-dependent system in rice[34] (Fig 3B). The transcriptional pattern of OsRboha implied that the PA-stimulated ROS generation of NADPH-oxidase dependence probably resulted from the PA modification of the enzyme rather than de novo protein synthesis (Fig 4B, C), and high PA might caused cell disruption leading to the decrease of OsRboha transcription. We did not find much influence of $\mathrm{H}_{2} \mathrm{O}_{2}$ on cell death induced by PA (Fig 3C), indicating that the $\mathrm{H}_{2} \mathrm{O}_{2}$ generation was not a key determinant of the cell death process as observed in tobacco cells [37]. The result implied that the relation between the hypersensitive cell death and the oxidative burst is very complicated[36].

We performed FACS to show the direct evidence of rice cells undergoing apoptosis[30] (Fig 2C). One phenomenon in plant cells undergoing PCD, but not universal, is DNA laddering resulting from the cleavage of plant nuclear DNA[38, 39]. However, as a matter of fact, no DNA laddering has been observed in all rice-pathogen interactions studied so far. Instead, cell viability via Evans blue staining is usually adopted to document PCD in rice cells $[27,40]$. We also did not detect this kind of DNA fragmentation either in the cells treated with PA or in the leaves during rice-M. grisea interactions ( $\mathrm{H} 7 \mathrm{R}, 7 \mathrm{~S}$ via $01-19 \mathrm{~B} 15)$ with the sensitive ApoAlert LM-PCR ladder assay approach (CLONTECH, CA) (data not shown).

The rice plants pretreated with PA gained protective enhancement against following fungal infection (Fig 5), and we demonstrated that the PA-mediated defense activation directly accounted for the enhancement of disease resistance. Our results indicated that, as a HR elicitor, PA efficiently activated rice defense responses including PCD, the oxidative burst and defense-related gene activation, probably leading to SAR, therefore had potential application as a new component of fungicide in plant protection. In another study, we also found PA induced strong HRlike responses in Arabidopsis, a dicot model plant (data not shown), indicating of its common eliciting function in plants. Certainly, further investigation is needed to clarify the mechanism of apoptosis and defense activation by PA in plants, focusing on the dissection of signaling pathways from biochemistry, cellular and molecular aspects.

\section{ACKNOWLEDGEMENTS}

We are thankful to Dr. Dudler for providing the PIR2 probe, Dr. Werner for the rice gp91phox homolog probe, Prof. Sun for the blast culture, and Prof. Ma for measurement of PA. We are also grateful to Ms. Meng for FACS test and Prof. Wei for protoplast preparation. This research is supported by the National Natural Science Foudation of China (30125030) and the Chinese Academy of Sciences project (KSCX2-SW-301-02). Z. He is a fellow of the CAS "One-Hundred Talent" program.

Received Jun 5, 2003

Revised Oct 10, 2003

Accepted Dec 6, 2003

\section{REFERENCES}

1 Fernandez-Pol JA, Hamilton PD, Klos DJ. Essential viral and cellular zinc and iron containing metalloproteins as targets for novel antiviral and anticancer agents: implications for prevention and therapy of viral diseases and cancer. Anticancer research 2001; 21:931-58.

2 Fernandez-Pol JA, Johnson GS. Selective toxicity induced by picolinic acid in simian virus 40-transformed cells in tissue culture. Cancer Research 1977; 37:4276-9.

3 Fernandez-Pol JA, Bono Jr VH, Johnson GS. Control of growth by picolinic acid: differential response of normal and transformedlls. Proc Natl Acad Sci USA 1977; 74:2889-93.

4 Frumento G, Rotondo R, Tonetti M, Damonte G, Benatti U, Ferrara GB. Tryptophan-derived catabolites are responsible for inhibition of $\mathrm{T}$ and natural killer cell proliferation induced by indoleamine 2, 3-dioxygenase. J Exp Med 2002; 196:459-68

5 Varesio L, Clayton M, Blasi E, Ruffman R, Radzioch D. Picolinic acid, a catabolite of tryptophan, as the second signal in the activation of IFN- $\gamma$-primed macrophages. J Immunol 1990; 145: 4265-71.

6 Pais TF, Appelberg R. Macrophage control of mycobacterial growth induced by picolinic acid is dependent on host cell apoptosis. J Immunol 2000; 164:389-97.

7 Ruffmann R, Schlick R, Chirigos MA, Budzynsky W, Varesio L. Antiproliferative activity of picolinic acid due to macrophage activation. Drugs Exptl Clin Res 1987; 10:607-14.

8 Bosco MC, Rapisarda A, Massazza S, Melillo G, Young H, Varesio L. The tryptophan catabolite picolinic acid selectively induces the chemokines macrophage inflammatory protein-1 alpha and -1 beta in macrophages. J Immunol 2000; 164:3283-91.

9 Rapella A, Negrioli A, Melillo G, Pastorino S, Varesio L, Bosco MC. Flavopiridol inhibits vascular endothelial growth factor production induced by hypoxia or picolinic acid in human neuroblastoma. Int J Cancer 2002; 99:658-64.

10 Fernandez-Pol JA, Klos DJ, Hamilton PD. Antiviral, cytotoxic and apoptotic activities of picolinic acid on human immunodeficiency virus-1 and human herpes simplex virus- 2 infected cells. Anticancer research 2001; 21:3773-6.

11 Ogata S, Inoue K, Iwata K, Okumura K, Taguchi H. Apoptosis induced by picolinic acid-related compounds in HL-60 cells. Biosci Biotechnol Biochem 2001; 65:2337-9.

12 Greenberg JT. Programmed cell death in plant-pathogen interactions. Annu Rev Plant Physiol Plant Mol Biol 1997; 48 525-45. 
13 De Jong AJ, Hoeberichts FA, Yakimova ET, Maximova E, Woltering EJ. Chemical-induced apoptotic cell death in tomato cells: involvement of caspase-like proteases. Planta 2000; 211: 656-62.

14 Stein JC Hansen G. Mannose induces an endonuclease responsible for DNA laddering in plant cells. Plant Physiol 1999; 121: 71-80.

15 Dixon RA, Harrison MJ, Lamb CJ. Early events in the activation of plant defense responses. Annu Rev Phytopathol 1994; 32 : 479-501.

16 Levine A, Tenhaken R, Dixon RA, Lamb CJ. Levine, A., Tenhaken, R., Dixon, R.A., Lamb, C. (1994). $\mathrm{H}_{2} \mathrm{O}_{2}$ from the oxidative burst orchestrates the plant hypersensitive disease resistance response. Cell 1994; 79:583-93.

17 Lamb C, Dixon RA. The oxidative burst in plant disease resistance. Annu Rev Plant Physiol Plant Mol Biol 1997; 48:251-75.

18 Ryals JA, Neuenschwander UH, Willits MG, Molina A, Steiner HY, Hunt MD. Systemic acquired resistance. Plant Cell 1996; 8: 1809-19.

19 Wäspi U, Schweizer P, Dudler R. Syringolin reprograms wheat to undergo hypersensitive cell death in a compatible interaction with powdery mildew. Plant Cell 2001; 13:153-61.

20 Koga J, Yamauchi T, Shimura M, Ogawa N, Oshimai K, Umemura K, Kikuchi M, Ogasawara N. Cerebrosides A and C, sphingolipid elicitors of hypersensitive cell death and phytoalexin accumulation in rice plants. J Biol Chem 1998; 273:31985-91.

21 Zimmerli L, Jakab G, Métraux JP, Mauch-Mani B. Potentiation of pathogen-specific defense mechanisms in Arabidopsis by $\beta$ aminobutyric acid. Proc Natl Acad Sci USA 2000; 97:12920-5.

22 Dowd PF. Relative inhibition of insect phenoloxidase by cyclic fungal metabolites from insect and plant pathogens. Nat Toxins 1999; 7:337-41.

23 Iwahashi H, Kawamori H, Fukushima K. Quinolinic acid, alphapicolinic acid, fusaric acid, and 2,6-pyridinedicarboxylic acid enhance the Fenton reaction in phosphate buffer. Chem Biol Interact 1999; 118:201-15.

24 Chen Z, Chen QF. The application of $\alpha$-picolinic acid on the screening of rice blast-resistant varieties. Acta Botanica Sinica 1993; 35:165-70.

25 Widiyanto SN, Mariani TS. In vitro selection and production of rice plantlets tolerant to the blast-toxin. Proc ITB 1995; 28 (suppl):19-27.

26 He Z, Dong H, Dong J, Li D Ronald P. Rice transcript Rim2 accumulates in response to Magnaporthe grisea and its predicted protein shares similarity with the proteins encoded by CACTA transposons. Mol Gen Genet 2000; 264:2-10.

27 He Z, Wang Z, Li J, Zhu Q, Lamb C, Ronald P, Chory J. Perception of brassinosteroids by the extracellular domain of the recep- tor kinase BRI1. Science 2000; 288:2360-3.

28 Peterhänsel C, Freialdenhoven A, Kurth J, Kolsch R, SchulzeLefert $\mathrm{P}$. Interaction analyses of genes required for resistance responses to powdery mildew in barley reveal distinct pathways leading to leaf cell death. Plant Cell 1997; 9:1397-409.

29 Kyozuka, J. \& Shimamoto, K. In: Lindsey K. ed. Plant Tissue Culture Manual B2. Kluwer: Dordrecht 1991:1-17.

30 O'Brien I, Reutelingsperger C, Holdaway KM. Annexin-V and TUNEL use in monitoring the progression of apoptosis in plants. Cytometry 1997; 29:28-33.

31 Low PS, Heinstein PF. Elicitor stimulation of the defense response in cultured plant cells monitored by fluorescent dyes. Arch Biochem Biophys 1986; 249:472-9.

32 Thoudal-Christensen H, Zhang Z, Wei Y, Collinge DB. Subcellular localization of $\mathrm{H}_{2} \mathrm{O}_{2}$ in plants. $\mathrm{H}_{2} \mathrm{O}_{2}$ accumulation in papillae and hypersensitive response during the barley-powdery mildew interaction. Plant J 1997; 6:1187-94.

33 Reimmann C, Dudler R. cDNA cloning and sequence analysis of a pathogen-induced thaumatin-like protein from rice (Oryza sativa). Plant Physiol 1993; 101:1113-4.

34 Keller T, Damude HG, Werner D, Doerner P, Dixon RA, Lamb C. A plant homolog of the neutrophil NADPH oxidase gp91phox subunit gene encodes a plasma membrane protein with $\mathrm{Ca}^{2+}$ binding motifs. Plant Cell 1998; 10:255-66.

35 Valent B, Farrall L, Chumley FG. Magnaporthe grisea Genes for Pathogenicity and Virulence Identified Through a Series of Backcrosses. Genetics 1991; 127:87-101.

36 Alvarez ME, Pennell RI, Meijer PJ, Ishikawa A, Dixon RA, Lamb C. Reactive oxygen intermediates mediate a systemic signal network in the establishment of plant immunity. Cell 1998; 92: 773-84.

37 Dorey S, Kopp M, Geoffroy P, Fritig B, Kauffmann S. Hydrogen peroxide from the oxidative burst is neither necessary nor sufficient for hypersensitive cell death induction, phenylalanine ammonia lyase stimulation, salicylic acid accumulation, or scopoletin consumption in cultured tobacco cells treated with elicitin. Plant Physiol 1999; 121:163-72.

38 Ryerson DE, Heath MC. Cleavage of nuclear DNA into oligonucleosomal fragments during cell death induced by fungal infection or by abiotic treatments. Plant Cell 1996; 8:393-402.

39 Tada Y, Hata S, Takata Y, Nakayashiki H, Tosa Y, Mayama S. Induction and signaling of an apoptotic response typified by DNA laddering in the defense response of oats to infection and elicitors. Mol Plant Microbe Interact 2001; 14:477-86.

40 Matsumura H, Nirasawa S, Kiba A, Urasaki N, Saitoh H, Ito M, Kawai-Yamada M, Uchimiya H, Terauchi R. Overexpression of Bax inhibitor suppresses the fungal elicitor-induced cell death in rice (Oryza sativa L.) cells. Plant J 2003; 33:425-34. 